\title{
Evaluation of the air-dry mass of vetch-cereal grass mixtures according to their optimality in the ratio of neutral-detergent (NDF) and acid- detergent fiber (ADF)
}

\author{
A S Skamarokhova ${ }^{1}, N A$ Yurina $^{1,2, *}, N A$ Bedilo $^{1}, D A$ Yurin $^{1}$, and $Y N$ Ashinov $^{3}$ \\ ${ }^{1}$ Krasnodar Research Centre for Animal Husbandry and Veterinary Medicine, Pervaya Liniya St., 1, \\ 350004, Krasnodar, Russian Federation \\ ${ }^{2}$ Kuban State Agrarian University named after I. T. Trubilin, Kalinina St., 13, 350044, Krasnodar, \\ Russian Federation \\ ${ }^{3}$ Maikop State Technological University, Pervomayskaya St., 191 , 385500, Maikop, Russian \\ Federation
}

\begin{abstract}
On the experimental field an experiment was laid to study the productivity of two types of winter vetch: Hungarian vetch (Vicia pannonica Granz) varieties Orlan and Chernomorskaya and downy vetch (Vicia villosa op Roth) varieties Lugovskaya 2 and Glinkovskaya. The vetch was sown in a mixture with winter wheat (Triticum aestivum L.) variety Tanya. Various doses of mineral fertilizers. Phosphorus (superphosphate) and potassium (potassium chloride) were introduced during sowing, nitrogen (calcium nitrate) - as early spring feeding. As a control, we studied the variety of furry vetch Lugovskaya 2 , since this is the most popular variety of winter vetch in the Krasnodar Territory. The soils of the experimental plots are represented by leached, low-humus heavy loamy powerful chernozem. Due to the limited feed intake, the diets of high-yielding cows are rich in highly digestible non-structural carbohydrates (ADF), which fermentation leads to the formation of a large amount of propionic acid in the rumen with a strong acidic effect and, conversely, NDF fermentation is slower and on a smaller scale. The variant winter wheat Tanya + winter vetch Lugovskaya 2 - is closer to the optimum in the second cut. The rest of the experimental options of vetchwheat and vetch-triticale grass mixtures also have a negative fiber balance, which is not acceptable for feeding high-producing dairy cattle.
\end{abstract}

\section{Introduction}

NDF (neutral detergent fiber) is considered today as the most suitable parameter for fiber characterization, because NDF contains the most important constituents of plant cell walls (cellulose, hemicellulose and lignin) and thus makes it possible to divide carbohydrates into structural and non-structural (NDF, ADF). The big challenge in feeding high yielding cows

\footnotetext{
*Corresponding author: naden8277@ mail.ru
} 
is to meet the energy requirements of the animals while still providing the rumen with enough fibrous matter to allow normal rumen stability. Due to the limited feed intake, the diets of high-yielding cows are rich in highly digestible non-structural carbohydrates (ADF), which fermentation leads to the formation of a large amount of propionic acid in the rumen with a strong acidic effect and, conversely, NDF fermentation is slower and on a smaller scale. Fiber content and energy concentration are inversely related. In addition, fiber plays an important role in the formation of layers of rumen content (a mat of coarse particles that floats on a liquid containing small particles) [1-4].

Studies to solve the problem of feed production and the production of vegetable protein in different agroecological zones, economic regions and individual regions of the Russian Federation were carried out by many authors who found that in each soil-climatic zone there is some determining factor of the minimum, at the onset of which there is a sharp decrease in the productivity of most crops. In particular, in the steppe regions of the Krasnodar Territory, this factor is moisture. It is almost impossible to accurately predict the distribution of precipitation for individual growing periods. In some years, a lack of moisture leads to a sharp decrease in the corn yield, a reduction to critical volumes of silage harvesting, and also to a decrease in its quality [5-7].

By cultivating perennial and annual legume-grass mixtures for silage and haylage, drought damage can be minimized.

Annual legume-grass mixtures consisting of winter vetch and winter wheat or triticale are a good alternative to crops of perennial grasses. Winter vetch is one of the main lactic forage crops in winter crops used in dairy farming. In terms of fodder qualities, it is not inferior to alfalfa, clover, peas and other legumes. In addition, winter vetch is a catch crop, therefore it does not occupy an independent crop rotation field, allowing intensive use of arable land in livestock farms, and, moreover, improves soil fertility due to the symbiotic assimilation of atmospheric nitrogen. It is a supplier of carotene deficient for animals (57$78 \mathrm{mg} / \mathrm{kg}$ in green mass, $37 \mathrm{mg} / \mathrm{kg}$ in hay) and lysine (5\% of the total amount of protein) [8-11].

The current state of field fodder production in the Krasnodar Territory is characterized by an extensive level of management due to the irrational structure of sown areas, a high proportion of grain and tilled crops, a low proportion of perennial grasses, primarily legumes, and insufficient fertilization. The low productivity of forage crops on arable land and the predominance of cereals in their species composition determine the insignificant efficiency of forage crops in the farming system and crop rotation. To provide feed for one cow, even with a milk yield of $3500 \mathrm{~kg}$ of milk per year, at least 2.0 hectares of arable land are required. Due to the insufficient proportion of legumes, the provision of animals is insufficiently satisfied, and the consumption of fodder for the production of livestock products is 1.3-1.4 times higher than the standards. An increase in the share of legumes and legume-cereal plant materials up to $70 \%$ will ensure an increase in the content of crude protein in dry matter of bulk feeds up to $14-15 \%$.

Increasing the protein nutritional value and quality of feed based on optimizing the structure of sown areas will reduce their consumption for livestock production by $20-25 \%$ [12-15].

\section{Materials and methods}

On the experimental field of the Federal State Budgetary Scientific Institution Krasnodar Research Centre for Animal Husbandry and Veterinary Medicine from 01.10.2018 to 10.07.2019, an experiment was laid to study the productivity of two types of winter vetch: Hungarian vetch (Vicia pannonica Granz) varieties Orlan and Chernomorskaya and downy vetch (Vicia villosa op Roth) varieties Lugovskaya 2 and Glinkovskaya. The vetch was 
sown in a mixture with winter wheat (Triticum aestivum L.) variety Tanya. Various doses of mineral fertilizers $\left(\mathrm{N}_{20} \mathrm{P}_{20} \mathrm{~K}_{20}, \mathrm{~N}_{40} \mathrm{P}_{40} \mathrm{~K}_{40}, \mathrm{~N}_{60} \mathrm{P}_{60} \mathrm{~K}_{60}\right)$ were applied according to options. Phosphorus (superphosphate) and potassium (potassium chloride) were introduced during sowing, nitrogen (calcium nitrate) - as early spring feeding. As a control, we studied the variety of furry vetch Lugovskaya 2, since this is the most popular variety of winter vetch in the Krasnodar Territory. The soils of the experimental plots are represented by leached, low-humus heavy loamy powerful chernozem.

The research was carried out according to the "Methodology of field experiment" by B.A. Dospekhov and the Methodological instructions of the All-Russian Research Institute of Forages named after V.R. Williams. Evaluation of the air-dry mass of vetch-cereal grass mixtures in the ratio of neutral-detergent (NDF) and acid-detergent fiber (ADF) was carried out in vitro.

The purpose of this research is to find out which of the presented grass mixtures is the most optimal in the NDF / ADF ratio in vetch-cereal hay for the qualitative feeding of highyielding dairy cattle.

Due to the limited feed intake, the diets of high-yielding cows are rich in highly digestible non-structural carbohydrates (ADF), which fermentation leads to the formation of a large amount of propionic acid in the rumen with a strong acidic effect and, conversely, NDF fermentation is slower and on a smaller scale. Fiber content and energy concentration are inversely related. In addition, fiber plays an important role in the formation of layers of rumen content (a mat of coarse particles that floats on a liquid containing small particles).

The minimum amount of fiber of the right quality and physical condition is especially important for:

- normal fermentation in the rumen;

- maximum feed and energy consumption;

- optimal synthesis of milk fat;

- prevention of health problems after calving.

The need for fiber depends on the level of productivity and weight of the animal, the properties of the fiber, the buffer capacity of the feed and the frequency of feeding.

If the amount of structural fiber is below the critical value, the chewing time of the cud decreases and, as a result, the secretion of saliva. This lowers the $\mathrm{pH}$ and the ratio of acetate to propionate, leading to a decrease in milk fat. Low NDF content in the diet affects rumen and cow health. In the short term, too little fiber leads to subclinical acidosis or clinical acidosis. Long-term inadequate fiber provision leads to hoof problems and displaced abomasum. NDF content and rumen $\mathrm{pH}$ are inversely related, since NDF (from roughage), on the one hand, has a structural effect and stimulates saliva secretion. On the other hand, NDF is fermented more slowly and less than ADF.

\section{Results and discussion}

In order to find out which grass mixture is the most balanced for feeding cattle, the analysis of the air-dry mass (hay) of the grass mixtures was carried out using the Van Soest method. This method in a laboratory way determines the amount of neutral detergent fiber (NDF), and then acid detergent fiber (ADF). Requirements for NDF and ADF indicators are given in table 1 . 
Table 1. Requirements for NDF and ADF indicators for cattle ration.

\begin{tabular}{|c|c|c|}
\hline Indicators & Minimum value & Maximum value \\
\hline $\begin{array}{c}\text { NDF, \% in dry matter of the } \\
\text { diet }\end{array}$ & 28 & 40 \\
\hline $\begin{array}{c}\text { NDF from basal feed, \% in } \\
\text { dry matter of the basal feed }\end{array}$ & 22 & 32 \\
\hline $\begin{array}{c}\text { ADF, \% in dry matter of the } \\
\text { diet }\end{array}$ & 16 & 24 \\
\hline
\end{tabular}

The balance of ADF and NDF in the studied grass mixtures without fertilization is presented in table 2 .

Table 2. Content of ADF and NDF in the air-dry mass of annual vetch-cereal grass mixtures (control).

\begin{tabular}{|c|c|c|}
\hline Grass mixture option & NDF, \% & ADF, \% \\
\hline \multicolumn{2}{|c|}{ Phase of the beginning of heading of cereals- vetch budding (06.05.2019) } \\
\hline $\begin{array}{c}\text { Winter triticale Swat + winter } \\
\text { vetch Lugovskaya 2 }\end{array}$ & 50.8 & 29.9 \\
\hline $\begin{array}{c}\text { Winter wheat Tanya + winter } \\
\text { vetch Lugovskaya 2 }\end{array}$ & 46.4 & 33.0 \\
\hline $\begin{array}{c}\text { Winter triticale Swat + } \\
\text { Hungarian vetch Orlan }\end{array}$ & 28.1 & 19.2 \\
\hline $\begin{array}{c}\text { Winter wheat Tanya + } \\
\text { Hungarian vetch Orlan }\end{array}$ & 51.5 & 31.0 \\
\hline \multicolumn{2}{|c|}{ Flowering phase of cereals - beginning of bean formation of vetch (26.05.2019) } \\
\hline $\begin{array}{c}\text { Winter triticale Swat + winter } \\
\text { vetch Lugovskaya 2 }\end{array}$ & 38.8 & 31.9 \\
\hline $\begin{array}{c}\text { Winter wheat Tanya + winter } \\
\text { vetch Lugovskaya 2 }\end{array}$ & 45.0 & 36.4 \\
\hline $\begin{array}{c}\text { Winter triticale Swat + } \\
\text { Hungarian vetch Orlan }\end{array}$ & 44.6 & 32.3 \\
\hline $\begin{array}{c}\text { Winter wheat Tanya + + } \\
\text { Hungarian vetch Orlan }\end{array}$ & 45.6 & 28.4 \\
\hline
\end{tabular}

Based on the results of table 2, it can be concluded that the most optimal balance of NDF and ADF (based on the data in Table 1) contains a grass mixture of winter triticale Swat + Hungarian vetch Orlan in the budding phase, which was (NDF / ADF) 28.1 / 19. 2. This ratio of structural carbohydrates is closest to the optimum. All other test samples are considered options with negative fiber ratio (table 3 ). 
Table 3. The content of ADF and NDF in the air-dry mass of annual vetch-cereal grass mixtures with the introduction of mineral fertilizers.

\begin{tabular}{|c|c|c|}
\hline Grass mixture option & NDF, $\%$ & ADF, \% \\
\hline \multicolumn{2}{|c|}{ Phase of the beginning of heading of cereals- vetch budding (06.05.2019) } \\
\hline $\begin{array}{c}\text { Winter triticale Swat + winter } \\
\text { vetch Lugovskaya 2, } \mathrm{N}_{20} \mathrm{P}_{20} \mathrm{~K}_{20}\end{array}$ & 49.8 & 29.5 \\
\hline $\begin{array}{c}\text { Winter wheat Tanya }+ \text { winter } \\
\text { vetch Lugovskaya 2, } \mathrm{N}_{20} \mathrm{P}_{20} \mathrm{~K}_{20}\end{array}$ & 50.4 & 30.5 \\
\hline $\begin{array}{c}\text { Winter triticale Swat }+ \text { winter } \\
\text { vetch Lugovskaya 2, } \mathrm{N}_{40} \mathrm{P}_{40} \mathrm{~K}_{40}\end{array}$ & 48.7 & 38.3 \\
\hline $\begin{array}{c}\text { Winter wheat Tanya }+ \text { winter } \\
\text { vetch Lugovskaya 2, } \mathrm{N}_{40} \mathrm{P}_{40} \mathrm{~K}_{40}\end{array}$ & 34.5 & 25.8 \\
\hline \multicolumn{2}{|c|}{ Phase of flowering of cereals - beginning of bean formation of vetch $(26.05 .2019)$} \\
\hline $\begin{array}{c}\text { Winter triticale Swat }+ \text { winter } \\
\text { vetch Lugovskaya 2, } \mathrm{N}_{20} \mathrm{P}_{20} \mathrm{~K}_{20}\end{array}$ & 36.4 & 23.9 \\
\hline $\begin{array}{c}\text { Winter wheat Tanya }+ \text { winter } \\
\text { vetch Lugovskaya } 2, \mathrm{~N}_{20} \mathrm{P}_{20} \mathrm{~K}_{20}\end{array}$ & 45.1 & 34.0 \\
\hline $\begin{array}{c}\text { Winter triticale } \mathrm{Swat}+\text { winter }_{21} \\
\text { vetch Lugovskaya } 2, \mathrm{~N}_{40} \mathrm{P}_{40} \mathrm{~K}_{40}\end{array}$ & 40.3 & 31.8 \\
\hline $\begin{array}{c}\text { Winter wheat Tanya }+ \text { winter } \\
\text { vetch Lugovskaya } 2, \mathrm{~N}_{40} \mathrm{P}_{40} \mathrm{~K}_{40}\end{array}$ & 48.5 & 30.0 \\
\hline
\end{tabular}

The options with the use of mineral fertilizers are less close in terms of the optimal NDF / ADF ratio for cattle. The most balanced in terms of fiber content of all the options presented should be considered the winter wheat Tanya + winter vetch Lugovskaya 2, $\mathrm{N}_{40} \mathrm{P}_{40} \mathrm{~K}_{40}$. (ADF / NDF) $34.5 / 25.8$, obtained during mowing in the phase of heading of cereals - budding of vetch and variant of winter triticale Swat + winter vetch Lugovskaya 2, $\mathrm{N}_{20} \mathrm{P}_{20} \mathrm{~K}_{20}$ (mowing in the phase of flowering cereals - bean formation) (ADF / NDF) 36.4 / 23.9. In other test samples, an overestimation of the ADF is observed, which leads to a further decrease in the quality of feed.

The degree of reliability of the results is reflected in the data in table 4, which shows the statistical processing of data on mowing. Among the vetch-triticale grass mixtures, the highest quality content of structural carbohydrates is contained in the sample winter triticale Swat + Hungarian vetch Orlan - $28.1 \pm 0.31 / 19.2 \pm 0.19$, which is $43.5 \%\left(\mathrm{~N}_{20} \mathrm{P}_{20} \mathrm{~K}_{20}\right)$ and $42.5 \%\left(\mathrm{~N}_{20} \mathrm{P}_{20} \mathrm{~K}_{20}\right)$ less in NDF and by $35.1 \%\left(\mathrm{~N}_{20} \mathrm{P}_{20} \mathrm{~K}_{20}\right)$ and $49.9 \%\left(\mathrm{~N}_{20} \mathrm{P}_{20} \mathrm{~K}_{20}\right)$ less in ADF. Variants of vetch-wheat grass mixtures also have a negative fiber balance, which is not acceptable for feeding high-producing cattle. 
Table 4. Biometric processing of the results obtained in the first cut.

\begin{tabular}{|c|c|c|c|}
\hline \multirow{2}{*}{ Options } & Grass mixture & \multicolumn{2}{|c|}{ Heading - budding } \\
\cline { 3 - 4 } Control & $\begin{array}{c}\text { Winter triticale Swat + Hungarian vetch } \\
\text { Orlan }\end{array}$ & $28.1 \pm 0.31$ & $19.2 \pm 0.19$ \\
\hline $\mathrm{N}_{20} \mathrm{P}_{20} \mathrm{~K}_{20}$ & $\begin{array}{c}\text { Winter triticale Swat }+ \text { Hungarian vetch } \\
\text { Orlan, } \mathrm{N}_{20} \mathrm{P}_{20} \mathrm{~K}_{20}\end{array}$ & $49.73 \pm 0.2$ & $29.6 \pm 0.7$ \\
\hline $\mathrm{N}_{20} \mathrm{P}_{20} \mathrm{~K}_{20}$ & $\begin{array}{c}\text { Winter triticale Swat }+ \text { Hungarian vetch } \\
\text { Orlan, } \mathrm{N}_{40} \mathrm{P}_{40} \mathrm{~K}_{40}\end{array}$ & $48.9 \pm 0.56$ & $38.37 \pm 0.32 * * *$ \\
\hline Control & $\begin{array}{c}\text { Winter wheat Tanya }+ \text { winter vetch } \\
\text { Lugovskaya 2 }\end{array}$ & $46.37 \pm 0.91$ & $32.47 \pm 0.79$ \\
\hline $\mathrm{N}_{20} \mathrm{P}_{20} \mathrm{~K}_{20}$ & $\begin{array}{c}\text { Winter wheat Tanya }+ \text { winter vetch } \\
\text { Lugovskaya 2, } \mathrm{N}_{20} \mathrm{P}_{20} \mathrm{~K}_{20}\end{array}$ & $45.27 \pm 7.3$ & $36.43 \pm 0.3 * * *$ \\
\hline $\mathrm{N}_{40} \mathrm{P}_{40} \mathrm{~K}_{40}$ & $\begin{array}{c}\text { Winter wheat Tanya }+ \text { winter vetch } \\
\text { Lugovskaya 2, } \mathrm{N}_{40} \mathrm{P}_{40} \mathrm{~K}_{40}\end{array}$ & $34.53 \pm 0.64 *$ & $25.27 \pm 1.52$ \\
\hline \multicolumn{2}{|c|}{ Note: $*-\mathrm{p}<0.1, * *-\mathrm{p}<0.01, * * *$} \\
\end{tabular}

The variant winter wheat Tanya + winter vetch Lugovskaya $2-28.03 \pm 0.31 / 19.07 \pm$ 0.19 is closer to the optimum in the second cut. The rest of the experimental options of vetch-wheat and vetch-triticale grass mixtures also have a negative fiber balance, which is not acceptable for feeding high-producing dairy cattle (table 5).

Table 5. Biometric processing of the results obtained in the second cut.

\begin{tabular}{|c|c|c|c|}
\hline \multirow[t]{2}{*}{ Options } & \multirow[t]{2}{*}{ Grass mixture } & \multicolumn{2}{|c|}{ Flowering - bean formation } \\
\hline & & NDF, \% & $\mathrm{ADF}, \%$ \\
\hline Control & $\begin{array}{c}\text { Winter triticale Swat + winter vetch } \\
\text { Lugovskaya } 2\end{array}$ & $38.77 \pm 0.9$ & $36.5 \pm 0.68$ \\
\hline $\mathrm{N}_{20} \mathrm{P}_{20} \mathrm{~K}_{20}$ & $\begin{array}{l}\text { Winter triticale Swat }+ \text { winter vetch } \\
\text { Lugovskaya } 2, \mathrm{~N}_{20} \mathrm{P}_{20} \mathrm{~K}_{20}\end{array}$ & $36.5 \pm 0.68$ & $23.63 \pm 0.35$ \\
\hline $\mathrm{N}_{20} \mathrm{P}_{20} \mathrm{~K}_{20}$ & $\begin{array}{c}\text { Winter triticale Swat + winter vetch } \\
\text { Lugovskaya } 2, \mathrm{~N}_{40} \mathrm{P}_{40} \mathrm{~K}_{40}\end{array}$ & $40.8 \pm 0.25 * * *$ & $31.4 \pm 1.74 * * *$ \\
\hline Control & $\begin{array}{c}\text { Winter wheat Tanya }+ \text { winter vetch } \\
\text { Lugovskaya } 2\end{array}$ & $28.03 \pm 0.54$ & $19.07 \pm 0.52$ \\
\hline $\mathrm{N}_{20} \mathrm{P}_{20} \mathrm{~K}_{20}$ & $\begin{array}{c}\text { Winter wheat Tanya }+ \text { winter vetch } \\
\text { Lugovskaya } 2, \mathrm{~N}_{20} \mathrm{P}_{20} \mathrm{~K}_{20}\end{array}$ & $45.5 \pm 0.53 * * *$ & $34.07 \pm 0.58 * * *$ \\
\hline $\mathrm{N}_{40} \mathrm{P}_{40} \mathrm{~K}_{40}$ & $\begin{array}{c}\text { Winter wheat Tanya }+ \text { winter vetch } \\
\text { Lugovskaya } 2, \mathrm{~N}_{40} \mathrm{P}_{40} \mathrm{~K}_{40}\end{array}$ & $48.43 \pm 0.85 * * *$ & $29.87 \pm 1.52 * * *$ \\
\hline
\end{tabular}

\section{Conclusions}

The variant winter wheat Tanya + winter vetch Lugovskaya $2-28.03 \pm 0.31 / 19.07 \pm 0.19$ is closer to the optimum in the second cut. The rest of the experimental options of vetchwheat and vetch-triticale grass mixtures also have a negative fiber balance, which is not acceptable for feeding high-producing dairy cattle.

\section{References}

1. Manukyan I R, Basieva M A., Abiyev V B, Yurina N A, Gneush A N, Ashinov Y N 2019 Annals of Agri-Bio Research 24(2) 242-5 
2. Manukyan I R, Basieva M A, Gneush A N, Arutyunova G Y, Udychak M M, Yurin D A 2019 Scientific Papers Series Management, Economic Engineering in Agriculture and Rural Development 19(4) 159-166

3. Borisenko V V, Zholobova I S., Petenko A I, Gneush A N, Yurina N A 2018 J. of Pharmaceutical Sciences and Research 10(10) 2626-27

4. Makoi H J R Makoi, Ndakidemi P A 2009 African J. of Microbiology Research 3(11) 664-75

5. Sangeeta C Sindhu, Neelam Khetarpaul 2005 Nutrition \& Food Science 35(1) 20-7 doi: 10.1108/00346650510579108

6. Agegnehu G, Ghizaw A, Sinebo W 2006 Experimental Agriculture 42(4) 495-504 doi: 10.1017/S0014479706003863

7. Anusha M B, Shivanna N, Kumar G P, Anilakumar K R 2018 J. of Food Science and Technology 55(5) 1913-21 doi: 10.1007/s13197-018-3109-y

8. Yilmaz S, Özel A, Atak M, Erayman M 2015 Turkish J. of Agriculture and Forestry 39(1) 135-143 doi:10.3906/tar-1406-155

9. Hristov A N, Harper M T, Roth G, Canale C et al 2020 J. of Dairy Science 103(3) 2333-46 doi: 10.3168/jds.2019-16917

10. Santos-Silva J, Francisco A, Susana P Alves, Paula Portugal et al 2019 Meat Science 147 28-36 doi: 10.1016/j.meatsci.2018.08.015

11. Krogstad K C, Anderson J L, Herrick K J. 2020 Applied Animal Science 36(4) 503-8 doi: 10.15232/aas.2020-01994

12. Ma L, Zhao M, Zhao L S, Xu J C 2017 J. of Dairy Science 100(5) 3705-12 doi: 10.3168/jds.2016-11772

13. Wang H R., Chen Q, Chen L M, Ge R F et al. 2017 J. of Dairy Science 100(2) 1161-69 doi: 10.3168/jds.2016-10924.

14. Fustini M, Palmonari A, Canestrari G, Bonfante E et al 2017 J. of Dairy Science 100(6) 4475-83 doi: 10.3168/jds.2016-12266

15. Robin R White, Mary Beth Hall, Jeffrey L Firkins, Paul J Kononoff 2017 J. of Dairy Science 100(12) 9551-68 doi: 10.3168/jds.2017-12765 